УДК 378:37.011.3:316.61

DOI:

Ольга Гуманкова, кандидат педагогічних наук, доцент, доцент кафедри англійської мови $з$ методиками викладання в дошкільній та початковій освіті Житомирського державного університету імені Івана Франка Оксана Михайлова, кандидат педагогічних наук, доцент, дочент кафедри англійської мови з методиками викладання в дочкільній та початковій освіті Житомирського державного університету імені Івана Франка

\title{
ІНТЕГРАЦІЯ У НАВЧАННІ ІНОЗЕМНОЇ МОВИ ДІТЕЙ ДОШКІЛЬНОГО ВІКУ
}

У статті висвітлено питання реалізації інтеграції у навчанні іноземної мови дітей дошкільного віку. Конкретизовано поняття “міжпредметна інтеграція”. Розглянуто змістові та процесуальні аспекти інтеграції освітньої лінії “Іноземна мова” з іншими лініями розвитку дошкільників. Розкрито практичні иляхи реалізації міжпредметної інтеграції на заняттях англійської мови в закладах дошкільної освіти.

Ключові слова: інтеграчія; міжпредметна інтеграчія; освітні лінї; навчання іноземної мови; діти дошкільного віку.

Puc. 1. Jim. 5.

Olha Humankova, Ph.D.(Pedagogy), Associate Professor, Associate Professor of the English Language and Primary ELT Methodology Department Zhytomyr Ivan Franko State University

Oksana Mykhaylova, Ph.D.(Pedagogy), Associate Professor, Associate Professor of the English Language and Primary ELT Methodology Department Zhytomyr Ivan Franko State University

\section{INTEGRATION IN TEACHING A FOREIGN LANGUAGE TO CHILDREN OF PRESCHOOLAGE}

The article deals with the problem of the realization of integration in the process of teaching a foreign language to children of preschool age. Integration is viewed as an important means of contemporary preschool educational system modernization as it helps children to get a unified, holistic vision of reality, synchronizes and synergistically unites cognitive and game activities of children in the field of learning content assimilation.

The authors specify the meaning of the concept "interdisciplinary integration" consider this type of integration the most effective in teaching a foreign language to children of preschool age, as it is based on establishing relationships between different educational lines of preschool children, highlighted in syllabus requirements for preschool educational institutions where a foreign language, namely English is a focal point.

The interdisciplinary integration gives an opportunity to ensure the content of English language assimilation by children, involving the knowledge and skills that they obtained in different fields.

The authors analyze the syllabus requirements, define the content and procedural aspects of integration of the educational line "Foreign Language with lines: "Child's Personality", "Child in the World of Culture", "Child's Activity", Child in Sensory and Cognitive Development "Child's speech development", "Child in Natural Environment", "Child in a society".

The practical ways of the realization of interdisciplinary integration based on combination of language and speech activity of the learners with musical, art, physical, cognitive, labour, drama activities are described. The succession of the teachers' actions in the process of integration incorporation into the context of English language classes in preschool institution is explained.

Keywords: integration; interdisciplinary integration; educational lines, teaching a foreign language; children of preschool age.

П остановка проблеми. Свроінтеграція української держави є чинником, який активізуєпроблемунавчання іноземних мов на всіх етапах здобуття освіти. Важливість вивчення іноземних мов з раннього віку задекларована у провідних освітніх документах, зокрема у Базовому компоненті дошкільної освіти, програмі розвитку дитини дошкільного віку “Я у Світі”. Оволодіння іноземною мовою, а саме, основам елементарної іншомовної комунікативної компетентності стає важливим надбанням сучасної дитини дошкільного віку, яке забезпечує наступність дошкільного та шкільного етапів освіти, створює фундамент для шкільного іншомовного навчання, яке, згідно з вимогами концепції Нової Української школи, побудовано на компетентнісній основі. Іншомовна освіта підпорядковується тенденціям модернізації 
дошкільної освіти, віддзеркалює загальні напрями еволюції форм, методів, засобів навчання, потребує узгодження з вимогами сьогодення на загальнодидактичному та методичному рівнях.

Важливим напрямом розвитку сучасної системи дошкільної освіти $є$ імплементація ефективних дидактичних засобів, які сприятимуть становленню цілісного світобачення дошкільників, дозволять збагачувати пізнавальні можливості дітей на основі інтеграції видів діяльності, які набувають розвитку під час навчання в закладах дошкільної освіти (ЗДО), синхронізують та синергетично спрямують пізнавальні, ігрові дії дітей у сфері засвоєння змісту освіти.

3 огляду на зазначене, важливе місце в системі дошкільної освіти займає проблема реалізації інтеграції та інтегрованого навчання, які задовольняють характеристикам, переліченим попередньо. Це, в повній мірі, стосується й ранньої іншомовної освіти.

Аналіз останніх досліджень і публікацій. Проблема інтеграційних процесів в освіті знайшла обгрунтування в дослідженнях I. Беха, С. Гончаренка, I. Козловської, С. Клепко, А. Коломієць, В. Ільченко, О. Рудницької, О. Савченко, С. Ткаченко та інших.

Теоретико-практичні аспекти реалізації інтегрованого навчання в умовах ЗДО розглянуто Н. Гавриш, Л. Зайцевою, І. Кіндрат, Ю. Колягіной, К. Кругій,М. Лазаревою, І. Стеценко, М.Прокоф'євою та іншими.

Інтегрований підхід, інтеграція в контексті іншомовного навчання досліджувались С. Бахталіною, О. Бескорсою, О. Бігич, Л. Кадченко, С. Полат, С. Роман, Ю. Стиркіной.

Слід зауважити, що більшість наукових розвідок в сфері реалізації інтегрованого підходу, інтеграції у навчанні англійської мови присвячено шкільній освітній ланці.

Недостатньою залишається кількість наукових розробок саме для дошкільного освітнього етапу. Крім того, наукові погляди на проблему здійснення інтеграції у навчанні англійської мови дітей дошкільного віку потребують оновлення та корекції з урахуванням сучасних програмних вимог та тенденцій розвитку дидактичної системи дошкільної освіти. Зазначене актуалізує науковий пошук у сфері реалізації інтеграції у навчанні дошкільників англійської мови.

Постановка завдання. Метою нашої статті $\epsilon$ визначення аспектів інтеграції освітньої лінії "Іноземна мова" з іншими лініями розвитку дітей дошкільного віку, конкретизація практичних шляхів реалізації інтеграції на заняттях англійської мови в ЗДО.

Виклад основного матеріалу дослідження.
Інтеграція у навчанні англійської мови полягає в об'єднанні та взаємодії різнопредметних знань та способів їх застосування, а також в інтегруванні іншомовної діяльності з видами діяльності притаманними дітям: ігровою, руховою, музичною, драматичною, пізнавальною, художньою, трудовою тощо... [4, 79].

Інтеграція сприяє засвоєнню іноземної мови на високому рівні, оскільки навчання грунтується на раціональному синтезі мовленнєвих/мовних дій дітей з видами діяльності, які набувають розвитку під час організації життєдіяльності дошкільників за різними напрямами (лініями), передбаченими для ЗДО. За умови реалізації інтеграції у навчанні англійської мови, остання виступає загальною платформою, в якій відбувається зближення знань та різних видів діяльності дошкільників, які утворюють синтетичне ціле задля актуалізації завдань, які стоять перед ранньою іншомовною освітою.

Метою реалізації інтеграції у навчанні англійської мови $є$ забезпечення оптимальних умов для оволодіння основами англомовної комунікативної компетентності дітьми дошкільного віку на основі раціонального поєднання мовленнєвої активності, мовленнєвих дій $з$ діями та видами діяльності, які вже засвоєні та відповідають їх віковим інтересам. Щодо видів та форм інтеграції, зауважимо, що існують різноманітні класифікації, які відбивають специфіку досліджень науковців. Не маючи на меті детальний аналіз класифікацій, звернемось до розгляду окремих видів інтеграції, які найчастіше використовуються у навчанні іноземної мови.

У навчанні англійської мови часто йдеться про внутрішньопредметну інтеграцію, яка спрямовує діяльність учнів на органічне поєднання в ході заняття свідомих та підсвідомих компонентів в процесі навчання, що передбачає паралельне опанування знаннями, мовленнєвими навичками і вміннями $[2,82]$, тобто, йдеться про одночасне формування мовних знань, навичок та мовленнєвих умінь у ході одного заняття або уроку. В своєму дослідженні ми основний акцент робимо на реалізації міжпредметної інтеграції, яку розглядаємо як процес встановлення зв'язків різних освітніх ліній дітей дошкільного віку, де англійська мова стає центральним елементом, до якого систематично та цілеспрямовано підключаються знання та різні види діяльності, які дошкільники засвоїли в освітньому процесі ЗДО.

Міжпредметна інтеграція у навчанні дошкільників англійської мови пов'язана 3 інтеграцією останньої 3 предметами, які 
включаються в розклад занять дошкільників та забезпечують реалізацію завдань розвитку дітей дошкільного віку за освітніми напрямами, визначеними у відповідних державних програмах для ЗДО.

Іноземна мова (IM), на відміну від інших ліній розвитку, відкрита для чисельних міжпредметних зв'язків, використання знань, та вмінь дітей, отриманих $з$ різних галузей. Зв'язки іноземної мови 3 іншими лініями розвитку вважаємо за доцільне розглядати на змістово-інформаційному та процесуальному рівнях.

Міжпредметна інтеграція не є фіксованим, стабільним явищем. Відповідно, для її ефективної реалізації необхідно виділити змістові та процесуальні аспекти, які дозволять об'єднати англійську мову з іншими лініями розвитку дітей дошкільного віку.

Легко встановлюється зв'язок лінії розвитку “Іноземна мова (англійська)” з лінією розвитку “Особистість дитини”. На заняттях англійської мови вчителі не обходяться без рухливих ігор, вправ $з$ елементами рухової діяльності. Отже, змістові та процесуальні аспекти занять 3 фізичного розвитку інтегруються у контекст занять IM. Вправи загальнорозвивальні для різних груп м'язів, танцювальні вправи, вправи на шикування, вправи спортивного, змагального характеру легко імплементуються у методичні етапи занять IM.

Широко розповсюдженими $є$ вправи 3 використанням методу повної фізичної реакції, схемою яких є: мовленнєвий стимул - фізична реакція дітей, відповідно до отриманого стимулу [5]. Міжпредметна інтеграція реалізується, у такому випадку, на обох рівнях змістовоінформаційному та процесуальному. Виконуючи фізичні дії, команди, інструкції, які пропонуються англійською мовою, діти закріплюють знання лексико-граматичного матеріалу паралельно вдосконалюють уміння виконання аналогічних команд на заняттях 3 фізичного розвитку. I навпаки, виконання команд вихователя, які $є$ вже знайомими дітям, сприяє розумінню та запам'ятовуванню іншомовної лексики. Наочною ілюстрацією зв'язку зазначених ліній розвитку є систематичне проведення всередині занять IM фізкультхвилинок. У такому випадку, відбувається процесуальний рівень інтеграції.

Міжпредметна інтеграція освітньої лінії “Іноземна мова" з освітньою лінією “Дитина в соціумі” чітко простежується. Згідно показників розвитку за останньою лінією дитина на кінець шостого року життя має “усвідомлювати поняття родина, знає правила сімейного життя, обов’язки, традиції, родовід ... та має уявлення про ознаки, за якими визначають стан, вік, рід занять людини, диференціює рідних, знайомих, чужих людей ... має уявлення про різноманітність професій” [3, 198 - 199]. Відтак, на заняттях по темі “Му Family" (Моя Сім'я) дітям легше вдається сприйняти, зрозуміти іншомовну тематичну лексику, вирізнити родинні стосунки та називати членів родини англійською мовою. Описи складу своєї родини, які діти роблять на інших заняттях стають основою для описів за аналогією родин англійською мовою. Враховуючи те, що діти вже засвоїли норми поведінки $з$ іншими людьми: старшими, однолітками, вчитель легко може пояснити відмінності у привітаннях англійською мовою (Good morning. Hello. Нi). Також, у ході вивчення теми “Professions” (Професіï) вихователь спирається на знання дошкільників про професії, набуті на інших заняттях.

Інтеграція лінії “Іноземна мова" та лінії розвитку “Дитина у природному довкіллі" відбувається на основі того, що діти вже накопичили певний досвід спілкування з природою, володіють системою елементарних знань про природу планети Земля та Всесвіт [3]. У такому випадку актуалізується інтеграція змістових, процесуальних аспектів занять 3 пізнавального розвитку та занять з IM. Знання дітей в зазначеній сфері вдало розширяються, закріплюються та систематизуються на заняттях по темах "Animals and Birds" (Тварини і птахи), "Seasons” (Пори року), "Fruits and Vegetables" (Фрукти та овочі). Знаючи назви тварин та птахів, дітям легко усвідомити, зрозуміти та запам'ятати відповідну англомовну лексику. Разом з тим, вихователь поглиблює знання дітей про тварин, характеризуючи їх зовнішній вигляд, поведінку, місце проживання на заняттях англійської мови. Цікавим також для дітей є порівняння звуків, які видають тварини англійською та українською мовами. Дошкільники вже знають пори року та їх ознаки. Уміння опису та порівняння різної погоди та різних сезонів стають у нагоді, коли йдеться про відповідні описи та порівняння, які діти мають вчитись робити англійською мовою.

Не викликає сумніву органічність інтеграції освітньої лінії “Іноземна мова” з лінією “Дитина у світі культури”. Зокрема, на заняттях англійської мови вихователі часто звертаються до вивчення англомовних пісень, які, з одного боку, сприяють запам'ятовуванню мовного матеріалу, а з іншого, активізують знання та навички дітей, отримані під час занять 3 музичного мистецтва. Також, на заняттях англійської мови, з метою розвитку елементарних аудитивних навичок дошкільників, 
використовуються методичні прийоми 3 елементами малювання, розфарбовування, ліплення та аплікації. Набувають широкого використання вправи типу "Listen and Draw" (Слухаємо та малюємо), "Listen and Colour" (Слухаємо та розфарбовуємо).

Враховуючи те, що діти, згідно вимог програми для ЗДО, мають бути ознайомленими з різними видами театрів та мають досвід участі у театралізованій діяльності вихователі, з метою закріплення лексико-граматичного матеріалу, формування умінь іншомовного діалогічного мовлення, організовують інсценування, драматизацію реальних або уявних комунікативних ситуацій.

Чіткий взаємозв'язок простежується між лінією “Іноземна мова” та лінією “Діяльність дитини” (ігрова). Діти, під час навчання в ЗДО, ознайомлюються 3 правилами, як регуляторами ігор, вчаться узгоджувати дії 3 іншими учасниками, розуміти важливість дотримання ігрових правил тощо... [3] Крім того, що заняття англійської мови сприяють формуванню у дітей зазначених знань, вони ще й повністю будуються на основі ігрової діяльності. Гра є основним методом та засобом навчання іноземної мови дітей дошкільного віку. Під час участі в ігровій діяльності на заняттях IM, діти не тільки отримують можливості додаткового розвитку, а й закріплюють лексико-граматичний матеріал. Участь у парних, командних, фронтальних ігрових вправах не тільки закріплює навички узгодженої діяльності з іншими, навчає дошкільників співпраці, кооперації, а й дозволяє активізувати формування англомовної комунікативної компетентності шляхом залучення додаткових партнерів до спілкування.

Під час організації розвитку дітей дошкільного віку за лінією “Діяльність дитини” (трудова) діти отримують уміння працювати 3 різними матеріалами, розвивають необхідні для життя навички.

Міжпредметна інтеграція з англійською мовою реалізується, в даному випадку, шляхом використання завдань накшалт: "Make a collage" (Створи колаж); "Listen and Make" (Послухай та створи). Діти створюють та описують тематичні колажі, виготовляють подарунки, листівки, аплікації, отримуючи інструкції англійською мовою. Це дозволяє удосконалити загальні уміння дітей у сфері трудової діяльності і, разом з тим, сприяти розвитку іншомовних вмінь дошкільників.

Здійснення інтеграції іноземної мови з лінією “Дитина у сенсорно-пізнавальному розвитку” відбувається, коли діти визначають форму та розмір об'єктів англійською мовою, рахують предмети, іграшки, описують розташування меблів у кімнатах. У даному випадку міжпредметна інтеграція легко реалізується під час вивчення англомовних тем “Тоуs” (Іграшки), "House. Furniture” (Будинок. Меблі).

Реалізація інтеграційного зв'язку англійської мови з лінією “Мовлення дитини” забезпечується шляхом програвання комунікативних ситуацій, залучення дошкільників до створення описів предметів, явищ англійською мовою, використанням англомовних віршів, їх виразним декламуванням. Розуміння правильного розподілу слів у реченнях, правил їх побудови, отримане під час занять 3 розвитку мовлення може слугувати основою для розвитку умінь англомовного монологічного мовлення дошкільників. Відпрацювання розмовних формул, кліше, встановлення їх функціонального наповнення відбувається на заняттях англійської мови під час програвання різноманітних ситуацій у форматі “Розмовляємо $з$ англійськими друзями".

Підсумовуючи зазначене попередньо, відмічаємо, що освітня лінія “Іноземна мова" та заняття $з$ англійської мови, як засіб розвитку дошкільників у цій сфері, є відкритими для інтеграції з усіма лініями розвитку дошкільників, визначеними в освітніх програмах для ЗДО. Міжпредментна інтеграція має розглядатись як процес цілеспрямованого створення зв'язків між заняттями англійської мови та іншими заняттями, які входять до розкладу дошкільників та систематично реалізовуватись на змістовому та процесуальному рівнях. Узагальнимо зазначене у вигляді схеми (рис. 1).

Щодо практичних шляхів реалізації міжпредметної інтеграції у навчанні англійської мови в ЗДО, ми повністю підтримуємо точку зору Є.Бахталіної про те, що інтеграція має відбуватись шляхом варіювання ігрових вправ, які дозволяють залучити вже засвоєні дошкільниками дії та види діяльності - музичні, танцювальні, художні тощо у контекст занять англійської мови $[1,3]$. Дослідницею пропонуються різні варіанти здійснення міжпредметної інтеграції у вигляді схем: мовна/мовленнєва дія + музична дія; мовна/ мовленнєва дія + рухова дія; мовна/мовленнєва дія + малювання, розфарбовування; мовна/ мовленнєва дія + театралізована дія; мовна/ мовленнєва дія + пізнавальна дія; мовна/ мовленнєва дія + трудова діяльність тощо $[1,9]$.

Фактично, міжпредметна інтеграція здійснюється шляхом об'єднання англомовних дій дошкільників іншими діями, видами діяльності, вибір яких детермінується тематикою занять англійської мови. Безперечно, не є обов'язковим 


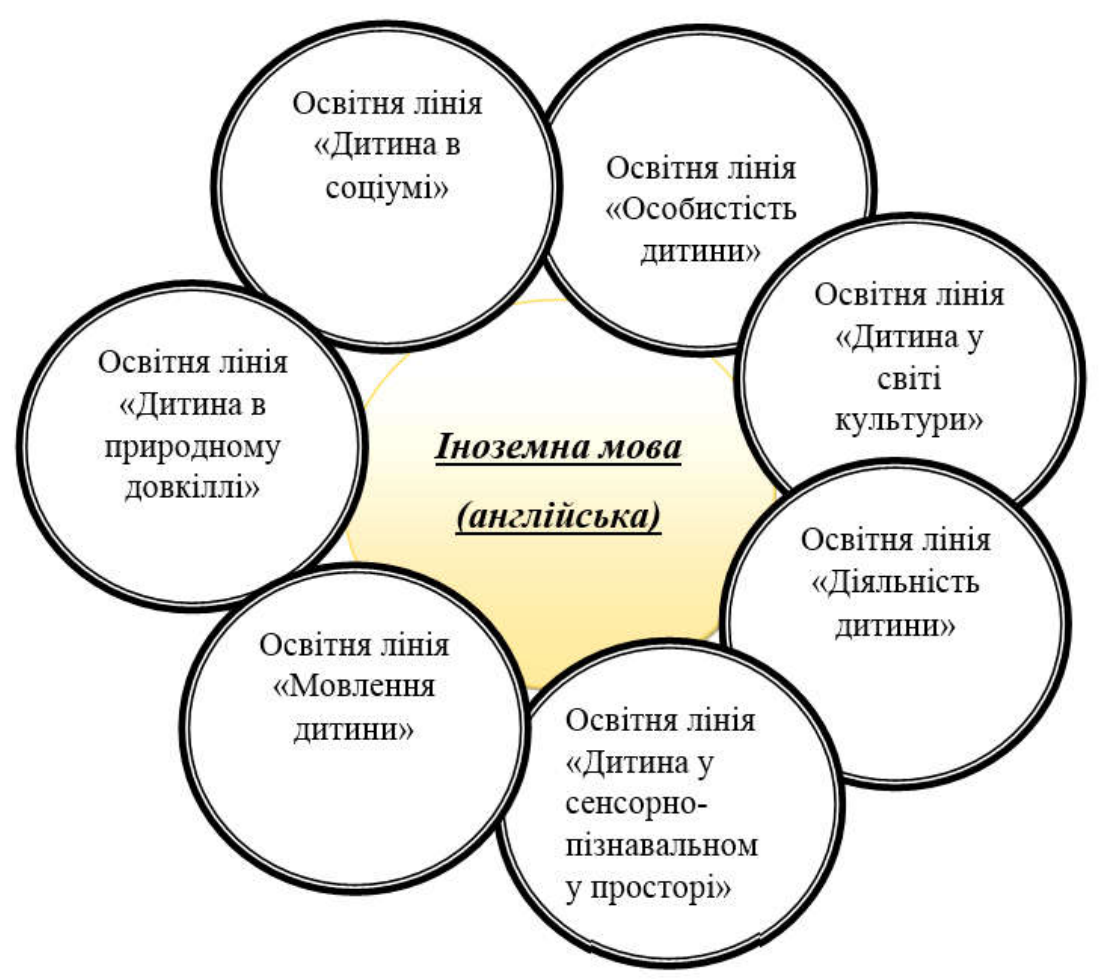

Рис. 1. Інтеграція освітньої лінії “Іноземна мова" 3 іншими лініями розвитку дошкільників

задіювати весь спектр міжпредметних зв'язків на одному занятті. Плануючи реалізацію міжпредметної інтеграції у тематичному підциклі занять англійської мови, вихователь має: проаналізувати мовний та мовленнєвий матеріал, який підлягає вивченню; визначити аспекти, рівні, напрями інтеграції 3 іншими заняттями дошкільників: відібрати види діяльності, які полегшать засвоєння конкретного матеріалу: підібрати вправи на основі інтеграції, які сприятимуть формуванню знань, навичок та вмінь дошкільників; методично коректно імплементувати відібрані вправи у контекст занять англійської мови.

Звернемось до конкретного прикладу. Так, в процесі вивчення теми "Animals and Birds" (Тварини і птахи) найдоцільнішим буде звернення до реалізації інтеграції із заняттями з музичного, пізнавального, фізичного та художнього розвитку шляхом об'єднання мовних/мовленнєвих дій дошкільників з музичними, пізнавальними, художніми та фізичними діями.

Дошкільники легше запам'ятають назви тварин та птахів, якщо розучування буде супроводжуватись рухами, які імітують рухи тварин або птахів (мовна дія + фізична дія). Запам'ятовуванню матеріалу сприятиме також розучування тематичної англомовної пісні (мовна дія + музична дія). Проведення ігрових вправ, на співставлення малюнків тварин з їжею, яку вони споживають, відгадування назв тварин за звуками, які вони видають забезпечить запам'ятовування лексико-граматичного матеріалу, мотивує дітей до співпраці (мовна дія + пізнавальна дія). Цікавими та захоплюючими стануть завдання для дошкільників, які, на основі англомовних інструкцій від вихователя, дозволять намалювати тварин або їх розфарбувати (мовна дія + художня дія). Зауважимо, що важливо методично-коректно імплементувати пропоновані ігрові завдання у методичні етапи формування англомовної мовної компетентності дошкільників.

Висновки та результати дослідження. Основним видом інтеграції, яка реалізується на заняттях англійської мови в ЗДО є міжпредметна інтеграція, яка грунтується на взаємодії освітньої лінії “Іноземна мова" з іншими лініями розвитку дошкільників. Англійська мова виступає центральною ланкою навколо якої об'єднуються та актуалізуються знання та дії, види діяльності, засвоєні дошкільниками на різних заняттях в ЗДО. Практична реалізація інтеграції відбувається шляхом синтезу англомовних мовних або мовленнєвих дій дошкільників 3 іншими видами 
дій та методично коректної імплементації таких дій у контекст занять англійської мови.

Результати проведеного дослідження не вичерпують всіх аспектів проблеми. Перспективи дослідження вбачаємо у розробці методичних рекомендацій для вчителів англійської мови ЗДО.

\section{ЛІТЕРАТУРА}

1. Бахталина Е. Ю. Интегрированное обучение английскому языку в детском саду : автореф. дис. на соиск. наук. степеня канд. пед. наук : спец. 13.00.02. Петрозаводск, 1998. 20 с.

2. Бігич О.Б., Бориско Н.Ф., Борецька Г.Е. та ін. Методика навчання іноземних мов і культур: теорія і практика : підручник для студ. лінгв. унтів і фак. ін. мов вищ. навч. закладів / під загальн. ред. С.Ю.Ніколаєвої. Київ, 2013. 590 с.

3. Програма розвитку дитини дошкільного віку "Я у Світі" (нова редакиія). У 2 ч. Ч. II. Від трьох до шести (семи) років / Аксьонова О.П., Анішук А.М., Артемова Л.В. та ін.; наук. кер. О. Л. Кононко. Київ, 2014. 452 с.

4. Роман С.В. Методика навчання англійської мови у початковій школі: Навчальний посібник. Київ, 2005. 208 с.

5. The Children's Response. TPR and Beyond. English Language Programs Devision, United States Information Agency Washington. D.C. Alemany Press, 1993. 75 p.

\section{REFERENCES}

1. Bakhtalyna, E. Yu. (1998). Integrirovannoe obuchenie angliyskomu yazyku v detskom sadu [Integrated teaching English in the kindergarten]. Extended abstract of Candidate's thesis. Petrozavodsk, 20 p. [in Russian].

2. Bihych, O.B., Borysko, N.F. \& Boretska, H.E. et al., Nikolayeva, S.Yu. (Ed.). (2013). Metodyka navchannia inozemnykh mov i kultur: teoriia i praktyka [Methodology of Teaching Foreign Language and Cultures: Theory and Practice]. A textbook for students of linguistic universities and faculties of foreign languages Higher Educational Establishments. Kyiv, 590 p. [in Ukrainian].

3.Aksonova, O.P.,Anishchuk, A.M. \& Artemova, L.V. et al., Kononko, O.L. (Ed.). (2014). Prohrama rozvytku dytyny doshkilnoho viku "Ia u Sviti" (nova redaktsiia) [Curriculumn of Preschoolers' Development "I am in the World" (new version)]. Part 2, Chapter II from three to six (seven). Kyiv, 452 p. [in Ukrainian].

4. Roman, S.V. (2005). Metodyka navchannia anhliiskoi movy u pochatkovii shkoli [Methodology of Teaching English in Primary School]. Tutorial. Kyiv, 208 p. [in Ukrainian].

5. The Children's Response. TPR and Beyond. English Language Programs Devision, United States Information Agency Washington. D.C. Alemany Press, 1993. 75 p. [in English].

Стаття надійшла до редакції 23.09.2019

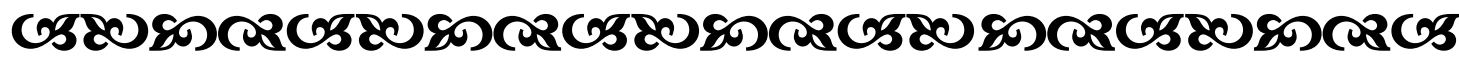

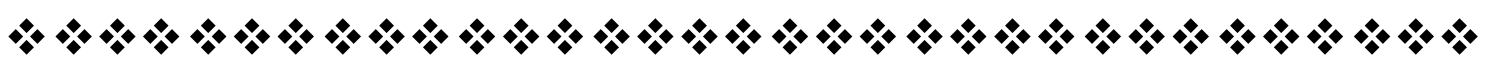

“Трагніть бути не просто успішною людиною, а иінним". Альберт Ейнштейн
один з найвизначніших бізиків ХХ століття

"Фосконалість - це не тоді, коли нічого додати, а тоді, коли нічого відняти". Антуан де Сент-Екзюпері французький письменник

"Коли зақриваються одні двері в щастя, відқривається інша. Але ми часто занадто довго дивимося на зақриті двері, щоб побачити, що нам відкрилося".

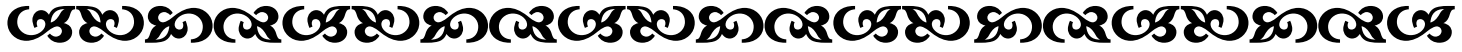

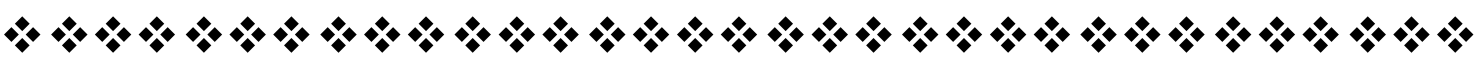

